\title{
Bladder cancer and occupation: a case-control study in northern Italy
}

\author{
Stefano Porru, Vito Aulenti, Francesco Donato, Paolo Boffetta, Raffaella Fazioli,
} Sergio Cosciani Cunico, Lorenzo Alessio

\begin{abstract}
Objectives-A hospital based case-control study was conducted between 1992 and 1993 in the province of Brescia, a highly industrialised area in northern Italy, to evaluate occupational risk factors of bladder cancer.

Methods-The study evaluated 355 histologically confirmed cases of bladder cancer ( 275 men, 80 women) and 579 controls affected by urological non-neoplastic diseases (397 men, 182 women). Lifetime occupational history, smoking and drinking habits, and sociodemographic characteristics were recorded by means of a structured questionnaire. Odds ratios (ORs) were computed with adjustment for age, smoking, alcohol and coffee consumption, education, and place of residence.
\end{abstract}

Results-A significant $(P<0.05)$ increase of risk of bladder cancer was found in men for labourers in the construction industry $(O R 2 \cdot 1,95 \%$ confidence interval $(95 \% \mathrm{CI}) 1 \cdot 1-3.9)$ and for recreational and cultural services (OR 5.0, 95\% CI 1.3-18.9). Increased risks, although not significant, were found for various other occupations and industries such as machinery mechanics, metal processers and polishers, blacksmiths, gunsmiths, painters; for transport workers, an increased risk with increasing duration of employment was found.

Conclusions-Occupational exposures seem to contribute to bladder cancer risk in the area under study.

(Occup Environ Med 1996;53:6-10)

Occupational Health,

University of Brescia,

Italy

$S$ Porru

R Fazioli

L Alessio

Institute of Urology, University of Brescia, Italy

V Aulenti

S Cosciani Cunico

International Agency for Research on

Cancer, Lion, France P Boffetta

Institute of Hygiene, University of Brescia, Italy

F Donato

Correspondence to:

Dr Stefano Porru, Institute of Occupational Health Spedali Civili di Brescia, P le Spedali Civili 1, 25123 Brescia, Italy.

Accepted 17 August 1995 metal workers, although ies. ${ }^{1-14}$ A number of aromatic amines have been recognised as bladder carcinogens such controversial evidence among different stud- as 4-aminobiphenyl, benzidine, 2-naphthylamine; other aromatic amines such as orthotoluidine, 4,4'methylene bis (2-chloroaniline), 4,4' methylene bis (2-methylaniline) and several polycyclic aromatic hydrocarbons have been recognised as suspected human carcinogens. ${ }^{131315}$ It has been estimated that up to $25 \%$ of cases of bladder cancer occurring in the general population can be attributed to occupational exposure. ${ }^{816}$

We present the results of a hospital based case-control study that was carried out to evaluate the relation between bladder cancer and occupation in the Province of Brescia, northern Italy. This area is characterised by a high density of industrial activities; all cancer mortality (410/100 000 in men and 281/100 000 in women in 1992-3) is higher than in Italy overall $(314 / 100000$ in men, $211 / 100000$ in women in 1991). ${ }^{17}$

\section{Subjects and methods}

All cases were subjects admitted between January 1992 and September 1993 for first diagnosis, treatment, or follow up of bladder cancer. All diagnoses were histologically confirmed and classified according to the WHO classification. ${ }^{18}$ Controls were patients admitted in the same period as cases for urological non-neoplastic diseases known to be unrelated to the exposures under study; male subjects were age matched (five year groups) whereas for women it was not possible to reach a complete match. All cases were recruited from the Urological Department of the General Hospital of Brescia, which is the reference hospital for cancer in the province. Controls were recruited from the same hospital as well as from two additional hospitals, where most non-neoplastic urological patients from the province are admitted. Cases and controls were interviewed by one interviewer, aware of the case-control status, who used a structured questionnaire that included questions on lifetime occupational history (for each job lasting at least six months, job title, plant activity, and type of production were recorded), lifelong smoking habits, current alcohol and coffee consumption, education level, and other information (such as consumption of artificial sweeteners, and use of phenacetin and hair dyes). About $25 \%$ of the questionnaires were rechecked by means of a telephone interview and no major disagreement with the original interview was recorded.

Job titles and plant activities were coded 
according to the international standard classification of occupations of the International Labour Office and to the international standard classification of all industrial activities of the United Nations. ${ }^{19} 20$

Coding was done not blindly by an occupational physician. A random 5\% sample of questionnaires was recoded blindly by another physician and no major disagreement was found. The average total daily alcohol consumption was computed from the ethanol content of wine, beer, and spirits. ${ }^{21}$

Data were analysed separately for men and women. Odds ratios (ORs) and 95\% confidence intervals ( $95 \%$ CIs) were computed for industries and occupations with at least 10 employed subjects, of whom there was at least one case and one control. Potential confounding was accounted for by computing ORs adjusted for age, education, residence, cigarette smoking, and coffee and alcohol drinking, by unconditional logistic regression analyses. The confounding variables were entered into the model as categorical. ${ }^{22}$

Analyses for duration of employment and latency from time of first diagnosis were carried out in men; the analysis was performed for three durations of employment $(<10$, $10-19,>20$ years). A test for trend in risk by latency or duration of employment was carried out among exposed subjects with an overall excess risk of 1.5 and with at least 10 exposed subjects for each category of duration and latency, by fitting logistic regression models in which the explanatory variable took the value 1,2 , or 3 depending on latency or duration group, with the zero level omitted. ${ }^{23}$ All statistical analyses were performed with the BMDP software (Dynamic version) for personal computers. ${ }^{24}$

\section{Results}

The study population consisted of 355 cases (275 men, 80 women) and 579 controls (397 men, 182 women, table 1$)$. Incident cases were 130 (105 men, 25 women). Only five cases and five controls refused the interview.

In men, mean (SD) age at interview was $60.9(11 \cdot 1$, range $24-84)$ years for cases and 59.7 (13.7, range 19-89) for controls. The largest group was the over $65 \mathrm{~s}$. Education level was similar among the two groups, although

Table 1 Sociodemographic characteristics of cases and controls

\begin{tabular}{|c|c|c|c|c|}
\hline & \multicolumn{2}{|l|}{ Men } & \multicolumn{2}{|l|}{ Women } \\
\hline & $\begin{array}{l}\text { Cases } \\
(275) \\
n(\%)\end{array}$ & $\begin{array}{l}\text { Controls } \\
(397) \\
n(\%)\end{array}$ & $\begin{array}{l}\text { Cases } \\
(80) \\
n(\%)\end{array}$ & $\begin{array}{l}\text { Controls } \\
(182) \\
n(\%)\end{array}$ \\
\hline \multicolumn{5}{|l|}{ Age (y): } \\
\hline $\begin{array}{l}<54 \\
55-64 \\
\geqslant 65\end{array}$ & $\begin{array}{r}78(28 \cdot 4) \\
88(32 \cdot 0) \\
109(39 \cdot 6)\end{array}$ & $\begin{array}{r}137(34 \cdot 4) \\
93(23 \cdot 4) \\
167(42 \cdot 1)\end{array}$ & $\begin{array}{l}21(26 \cdot 3) \\
20(25 \cdot 0) \\
39(48 \cdot 7)\end{array}$ & $\begin{array}{l}92(50 \cdot 5) \\
49(27 \cdot 0) \\
41(22 \cdot 5)\end{array}$ \\
\hline \multicolumn{5}{|l|}{$\begin{array}{l}\text { Education } \\
\text { (years of schooling): }\end{array}$} \\
\hline $\begin{array}{l}\text { (years of schooling): } \\
0-5\end{array}$ & $181(65 \cdot 8)$ & $223(56 \cdot 2)$ & $58(72 \cdot 5)$ & $112(61 \cdot 5)$ \\
\hline $6-8$ & $49(17.9)$ & $91(22.9)$ & $10(12 \cdot 5)$ & $37(20 \cdot 3)$ \\
\hline$\geqslant 9$ & $45(16.4)$ & $83(20.9)$ & $12(15 \cdot 0)$ & $33(18 \cdot 2)$ \\
\hline \multicolumn{5}{|l|}{ Residence: } \\
\hline $\begin{array}{l}\text { Brescia province } \\
\text { elsewhere }\end{array}$ & $\begin{array}{r}250(90 \cdot 9) \\
25(9 \cdot 1)\end{array}$ & $\begin{array}{r}321(80 \cdot 9) \\
76(19 \cdot 1)\end{array}$ & $\begin{aligned} 74 & (92 \cdot 5) \\
6 & (7 \cdot 5)\end{aligned}$ & $\begin{array}{r}126(69 \cdot 2) \\
56(30 \cdot 8)\end{array}$ \\
\hline
\end{tabular}

Table 2 Histological classification of cases of bladder cancer

\begin{tabular}{|c|c|c|}
\hline & \multirow{2}{*}{$\frac{\text { Total series }}{n(\%)}$} & \multirow{2}{*}{$\frac{\text { Incident cases }}{n(\%)}$} \\
\hline & & \\
\hline \multicolumn{3}{|l|}{ Histological type: } \\
\hline Papillary transitional & $\begin{aligned} 308(86 \cdot 7) \\
22(6 \cdot 2)\end{aligned}$ & $114(87 \cdot 7)$ \\
\hline $\begin{array}{l}\text { In situ } \\
\text { In situ + papillary }\end{array}$ & $9(2.5)$ & $1(0.8)$ \\
\hline Fibroepithelioma & $8(2 \cdot 3)$ & $4(3 \cdot 1)$ \\
\hline $\begin{array}{l}\text { Others } \\
\text { (inverted papillomas, } \\
\text { mixed) }\end{array}$ & $8(2 \cdot 3)$ & $4(3 \cdot 1)$ \\
\hline \multirow{2}{*}{\multicolumn{3}{|c|}{$\begin{array}{l}\text { Stage: } \\
\text { Early }\end{array}$}} \\
\hline & & \\
\hline$(\mathrm{Tis}, \mathrm{Ta}, \mathrm{T} 1)$ & $242(68 \cdot 1)$ & $87(66 \cdot 9)$ \\
\hline $\begin{array}{l}\mathrm{L} \text { ate } \\
(\mathrm{T} 2, \mathrm{~T} 3, \mathrm{~T} 4)\end{array}$ & $91(25 \cdot 6)$ & $28(21 \cdot 5)$ \\
\hline $\begin{array}{l}(\mathrm{T} 2, \mathrm{~T} 3, \mathrm{~T} 4) \\
\text { Unspecified }\end{array}$ & $22(6 \cdot 3)$ & $15(11.5)$ \\
\hline Grade: & & \\
\hline Low & $189(53 \cdot 2)$ & $66(50 \cdot 8)$ \\
\hline High & $152(42 \cdot 8)$ & $58(44 \cdot 6)$ \\
\hline Unspecified & $14(4 \cdot 0)$ & $6(4 \cdot 6)$ \\
\hline
\end{tabular}

cases had a higher percentage of people in the $<5$ years of education category. Most of the cases and controls lived in the province of Brescia.

In women, mean (SD) age for cases was $62 \cdot 8(12 \cdot 3$, range $26-87)$ years and $54 \cdot 1$ (14, range 21-86) for controls. Most of the cases were in the $>65$ category. Education had the same distribution as in men and there were more male controls than cases residing outside the province of Brescia.

About $7 \%$ of the cases were diagnosed between 1960 and 1980 , about $12 \%$ between 1981 and 1985, 45\% between 1986 and 1990, and $36 \%$ between 1991 and 1993 .

Table 2 shows the distribution of cases of bladder cancer according to histological type, stage, and grading. Cancers were mostly of the papillary transitional cell carcinoma type and of early stage and grade. The distribution for incident cases was similar.

Controls were mainly affected by urolithiasis (about $48 \%$ men and $84 \%$ women), prostatic adenoma (about 27\%), hydronephrosis (about $6 \%$ men and $13 \%$ women), or a combination of these diseases (about $5 \%$ ).

The mean number of reported occupations was 2.8 and 2.9 for male cases and controls, whereas for women it was $2 \cdot 1$ and $2 \cdot 4$.

Although all occupational and industrial groups were initially included in the analyses, the total number of ISIC codes was 105 in men and 50 in women, and of ISCO codes 180 in men and 60 in women, we only reported the results for occupations and industries selected according to the following criteria: number of exposed cases or controls (at least 10 exposed subjects); the relevance of the occupation or industry in the province of Brescia (such as metal working, or construction industry, textile industry, transports, agriculture); the ORs estimated (for example, including $O R$ above 1.5); and indicated by the scientific literature (considering for example, categories not selected according to the previous criteria and associated with high risk of bladder cancer, such as the rubber industry). Full results are available on request. 
Table 3 Odds ratios of bladder cancer according to job titles in men

\begin{tabular}{|c|c|c|}
\hline $\begin{array}{l}\text { fob category } \\
\text { (ISCO code) }\end{array}$ & $\begin{array}{l}\text { Exposed } \\
\text { cases/controls }\end{array}$ & OR(95\% CI $)$ \\
\hline Teachers (13) & $10 / 9$ & $1 \cdot 8(0 \cdot 6-5 \cdot 1)$ \\
\hline Post office clerks (37) & $10 / 9$ & $2 \cdot 0(0.7-5 \cdot 9)$ \\
\hline Office clerks (39310) & $12 / 16$ & $1.6(0.6-4 \cdot 0)$ \\
\hline $\begin{array}{l}\text { Cooks, waiters, } \\
\text { bartenders (53) }\end{array}$ & 9/9 & $1 \cdot 8(0 \cdot 6-5 \cdot 6)$ \\
\hline $\begin{array}{l}\text { Building caretakers, } \\
\text { charworkers, cleaners ( } 55)\end{array}$ & $7 / 13$ & $1.5(0.5-4 \cdot 7)$ \\
\hline $\begin{array}{l}\text { Protective service } \\
\text { workers (58) }\end{array}$ & $15 / 17$ & $1 \cdot 7(0.8-3 \cdot 9)$ \\
\hline Farmers (61) & $13 / 45$ & $0.5(0 \cdot 2-1 \cdot 0)$ \\
\hline $\begin{array}{l}\text { Agriculture and animal } \\
\text { husbandry workers (62) }\end{array}$ & $42 / 83$ & $0.5(0.3-0.9)$ \\
\hline $\begin{array}{l}\text { Production supervisors } \\
\text { and foremen }(700)\end{array}$ & $9 / 21$ & $0.7(0.3-1 \cdot 7)$ \\
\hline Miners (71105) & $9 / 3$ & $3.8(0.8-18 \cdot 3)$ \\
\hline Metal processers (72) & $31 / 33$ & $1 \cdot 2(0 \cdot 6-2 \cdot 1)$ \\
\hline Hot rollers $(72220)$ & $10 / 11$ & $0.8(0 \cdot 3-2 \cdot 2)$ \\
\hline \\
\hline machine-tool operators $(83)$ & $62 / 90$ & $0.9(0.6-1.3)$ \\
\hline Blacksmiths (831 10) & $8 / 5$ & $2 \cdot 1(0 \cdot 6-7 \cdot 5)$ \\
\hline Metal polishers $(83520)$ & $8 / 6$ & $1.6(0.5-5 \cdot 6)$ \\
\hline Gunsmiths (83920) & $16 / 10$ & $2 \cdot 1(0 \cdot 8-5 \cdot 5)$ \\
\hline $\begin{array}{l}\text { Machinery fitters, } \\
\text { assemblers, precision } \\
\text { instrument makers (84) }\end{array}$ & $38 / 60$ & $0 \cdot 7(0.4-1 \cdot 2)$ \\
\hline Machinery mechanic (84910) & $7 / 6$ & $2 \cdot 2(0.5-8.9)$ \\
\hline $\begin{array}{l}\text { Textile machinery } \\
\text { mechanic }(84945)\end{array}$ & $8 / 2$ & $5 \cdot 3(0 \cdot 8-34 \cdot 7)$ \\
\hline Electrical workers (85) & $12 / 17$ & $0.9(0.4-2 \cdot 2)$ \\
\hline $\begin{array}{l}\text { Plumbers, welders, sheet } \\
\text { metal workers (87) }\end{array}$ & $8 / 20$ & $0 \cdot 4(0 \cdot 1-1 \cdot 0)$ \\
\hline Painters (93) & $12 / 14$ & $1.4(0.6-3.5)$ \\
\hline $\begin{array}{l}\text { Labourers (construction) } \\
\text { (95110) }\end{array}$ & $40 / 24$ & $2 \cdot 1(1 \cdot 1-3 \cdot 9)$ \\
\hline Bricklayers (95120) & $28 / 37$ & $1 \cdot 1(0 \cdot 6-2 \cdot 1)$ \\
\hline $\begin{array}{l}\text { Material handling } \\
\text { operators, }(97)\end{array}$ & $20 / 30$ & $0.8(0.4-1.5)$ \\
\hline $\begin{array}{l}\text { Mobile crane } \\
\text { operators }(97330)\end{array}$ & $6 / 4$ & $2 \cdot 3(0.5-11.3)$ \\
\hline $\begin{array}{l}\text { Transport equipment } \\
\text { operators (98) }\end{array}$ & $39 / 93$ & $1 \cdot 0(0 \cdot 6-1 \cdot 7)$ \\
\hline Motor vehicle drivers (985) & $33 / 37$ & $0.9(0.5-1 \cdot 7)$ \\
\hline $\begin{array}{l}\text { Lorry and van driver } \\
\text { local, }(98550)\end{array}$ & $7 / 11$ & $0.5(0 \cdot 2-1 \cdot 6)$ \\
\hline $\begin{array}{l}\text { Lorry and van driver } \\
\text { long distance }(98560)\end{array}$ & $23 / 19$ & $1 \cdot 1(0 \cdot 5-2 \cdot 2)$ \\
\hline
\end{tabular}

OR estimated by logistic regression models including age, residence, education, smoking, and coffee and alcohol consumption.

Table 3 shows the relative risk estimates in men according to occupation. Significantly ( $P$ $<0.05$ ) increased ORs were found only for labourers in the construction industry. Other job titles showed non-significant increased risks; in particular miners, machinery mechanics (particularly in the textile industry), metal processers and polishers, blacksmiths, gunsmiths, and painters (especially in the con-

Table 4 Odds ratios of selected job titles by duration of employment in men

\begin{tabular}{lcccc}
\hline & \multicolumn{3}{c}{ Duration of employment $(y)$} & $\begin{array}{l}\text { Trend } \\
\text { test }\end{array}$ \\
\cline { 2 - 3 } fob category & $1-9$ & $10-19$ & $\geqslant 20$ & \\
\hline P value)
\end{tabular}

OR estimated by logistic regression models including age, residence, education, smoking, and coffee and alcohol con-

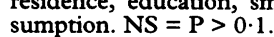

Table 5 Odds ratios of bladder cancer according to job titles in women

\begin{tabular}{lll}
\hline $\begin{array}{l}\text { fob category } \\
\text { (ISCO code) }\end{array}$ & $\begin{array}{l}\text { Exposed } \\
\text { cases/controls }\end{array}$ & OR $(95 \%$ CI) \\
\hline Teachers (13) & $8 / 13$ & $3 \cdot 6(0 \cdot 8-16 \cdot 3)$ \\
Sales workers (45) & $5 / 18$ & $0 \cdot 4(0 \cdot 1-1 \cdot 5)$ \\
Cooks, waiters, & $5 / 8$ & $1 \cdot 1(0 \cdot 3-4 \cdot 3)$ \\
$\quad$ bartenders (53) & & \\
Charworkers (55220) & $11 / 39$ & $0 \cdot 5(0 \cdot 2-1 \cdot 3)$ \\
Housewives (59910) & $44 / 85$ & $0 \cdot 9(0 \cdot 4-1 \cdot 7)$ \\
Spinners (75220) & $5 / 10$ & $0 \cdot 8(0 \cdot 2-3 \cdot 1)$ \\
Knitters (755) & $7 / 15$ & $0 \cdot 96(0 \cdot 3-2 \cdot 9)$ \\
Tailors, dressmakers (79) & $8 / 27$ & $0 \cdot 5(0 \cdot 2-1 \cdot 3)$ \\
Blacksmiths, toolmakers, & & \\
$\quad$ machine-tool operators (83) & $8 / 10$ & $1 \cdot 4(0 \cdot 4-4 \cdot 7)$ \\
Hand packers (97150) & $5 / 8$ & $2 \cdot 4(0 \cdot 6-10 \cdot 3)$ \\
\hline
\end{tabular}

OR estimated by logistic regression models including age residence, education, smoking, and coffee and alcohol consumption.

struction industry). Within industries, a significant OR was found only for recreational and cultural services (OR 5.0, 95\% CI 1.3-18.9, 10 cases, 4 controls); non-significantly increased ORs were noted in the textile industry (OR 1.3, 23 cases, 26 controls), wood products (OR 1.5, 11 cases, 9 controls), non metallic mineral products (OR 1.5, 16 cases, 15 controls), manufacture of machinery and equipment (OR 1.4, 42 cases, 42 controls), electricity, gas, and steam (OR 3.7, 7 cases, 5 controls), and ground transport industries (OR 3.6, 10 cases, 3 controls).

The latency analysis showed that most of the workers were in the category with 20 or more years of latency, for both ISCO and ISIC codes. Small numbers of exposed subjects in the other categories did not allow detailed analyses.

No test for linear trend is shown in detail, because almost none of the investigated occupations had an overall excess risk greater than 1.5 and at the same time 10 or more exposed subjects in each duration or latency category.

Table 4 shows results for duration of employment for selected occupations; although construction labourers (see also bricklayers for comparison)-who had an overall significant excess risk-showed no linear trend for duration, transport workers (and in particular motor vehicle drivers), a group of interest a priori but with no overall excess risk, showed a significant trend with duration of employment.

Analysis of duration of employment in other occupations did not suggest any trend.

For women (table 5), according to job titles classification, non-significantly raised ORs were detected for blacksmiths, tool makers, and machine tool operators, teachers, and handpackers.

For women employed in industrial activities, non-significantly increased ORs were noted in branches such as knitting mills (OR $1.5,10$ cases, 16 controls), retail trade (OR $1 \cdot 2,10$ cases, 19 controls), and education services (OR 2.6, 9 cases, 15 controls).

When the analysis was restricted to incident cases, the following occupational categories showed a notable change in the ORs: male painters (OR 2.2, 95\% CI 0.7-6.7), male charworkers $(1.6,0.4-6.8)$, housewives $(1.9$, 
$0 \cdot 6-6 \cdot 8)$, female spinners $(2 \cdot 6,0 \cdot 5-15 \cdot 2)$, and hand packers $(3 \cdot 9,0 \cdot 4-38 \cdot 3)$; for industrial categories changes in ORs were noted for men in agriculture and livestock production (1.0, $0 \cdot 2-6 \cdot 7)$, transportation $(0 \cdot 5,0 \cdot 2-1 \cdot 1)$, public administration and defence $(2 \cdot 5,1-6 \cdot 5)$, recreational and cultural services $(9 \cdot 7,1 \cdot 9-50)$ and, for women, retail trade $(0.4,0 \cdot 01-4 \cdot 3)$, education service $(1.9,0 \cdot 1-38 \cdot 9)$, and personal and household services $(2 \cdot 0,0 \cdot 5-7 \cdot 4)$.

\section{Discussion}

This was the first study in the province of Brescia to examine the relation between bladder cancer and occupation. The area is highly industrialised, with extensive metal and mechanical industries, construction, manufacture of textiles, and agriculture. On the other hand, activities traditionally associated with an increased risk of bladder cancer such as rubber and dyestuffs industries are not present.

The results in men showed a twofold significant excess risk for labourers in the construction industry. One explanation is chance. Another possible explanation might be the fact that these workers are expected to be exposed to several xenobiotics such as paints, asphalt, products of combustion (gasoline and diesel fumes) mineral oils, naphtha, solvents, grease, metals, and asbestos. This is mainly due to the great variety of job tasks and exposures they may encounter when helping or replacing skilled workers, such as the plumbers and pipefitters, painters, electricians, carperters, roofers, demolition and insulation workers, welders, and plasterers. The dirtyness of the type of work should also be considered. ${ }^{25}$

Other studies have found small increases in risk of urological cancer among construction workers. For example, in a study from the United States, ${ }^{8}$ in cement and concrete finishers an OR of $1.9(95 \%$ CI $0.8-4.9)$ was found adjusted for smoking and education, whereas for inspector, grader, foreman, and weigher the OR was $1.6(95 \% \mathrm{CI} 1 \cdot 1-2 \cdot 5)$, with a trend in risk with increasing duration of employment. Zheng et $a l^{12}$ found in China a standardised incidence ratio for bladder cancer of 1.1 in construction workers; an OR of $1.47(95 \%$ CI $0.8-2.5)$ was found by Becherini et al among Italian construction industry workers. ${ }^{26}$ Schumacher et $a l^{27}$ in the United States measured an OR of 1.45 (95\% CI 0.99-2.13) in men and 1.85 (95\% CI 0.36$8 \cdot 8$ ) in women in the construction industry and found an association with duration of exposure among men.

A standardised mortality ratio of 1.54 for cancer of the urinary system (95\% CI 0.94 $2 \cdot 37$, adjusted for smoking and alcohol consumption) was reported in the United States by Burkhart et $a l^{25}$ in other construction workers, a group that included labourers. It should also be stressed here that United States construction labourers have the highest death rates of any occupation and small positive associations between employment as a construction worker or labourer and cancer of organs other than the bladder were found, par- ticularly for stomach, larynx, lung, and pleura. ${ }^{25} 2829$

On the other hand, other studies in Germany, ${ }^{6}$ France, ${ }^{13}$ and Spain, ${ }^{30}$ reported no association between bladder cancer and occupation in the construction industry. For other significant associations found in this study no plausible biological mechanism can be suggested and chance remains the most likely explanation. In studies that generate hypotheses it is possible to identify false associations attributable to chance, due to the large number of categories concurrently analysed. Nonsignificant increased risks were found for various occupations or activities. Particularly relevant are, for the local population, the increased risks among machinery mechanics, metal workers, blacksmiths, gunsmiths, miners (involved especially in iron and fluorine mining), painters and workers in the manufacture of machines and equipment. These results are similar to the results of other casecontrol studies. ${ }^{35-10} 13$ 30-32

Of particular interest were the results for truck drivers, who showed a trend in risk of bladder cancer according to increasing duration of employment. Previous case-control studies, performed in various countries, showed conflicting results for truck drivers; however, many studies showed significantly increased risks after controlling for tobacco smoking, age, residence, with ORs generally in the range of $1 \cdot 1-4 \cdot 5$. In some of the studies, a significant trend in risk with increasing duration of lorry driving was noted. As the possible aetiologic agents, most of the studies referred to exposure to polycyclic aromatic hydrocarbons and in particular to diesel exhaust. ${ }^{46131527313334}$

This study was not designed to assess and evaluate exposure to specific chemicals to be linked with jobs. However, it is well known that metal and transport workers might be exposed to bladder carcinogens such as the polycyclic aromatic hydrocarbons; exposure to aromatic amines (at least as contaminants) cannot be excluded either. It must moreover be considered that a single job generally involves exposure to several substances and that it might be impossible to disentangle the effect due to a particular chemical. In this study, confounding by smoking does not seem likely. A joint effect of tobacco smoking and some occupational carcinogens such as asbestos or aromatic amines is well known. The synergism between tobacco smoking and occupational exposures was evaluated in this study for some categories, which had a sufficient number of subjects in any of the exposure categories, such as transport workers, construction labourers, bricklayers, gunsmiths, metal workers, blacksmiths, toolmakers, and machine-tool operators, machinery fitters, and assemblers. A multiplicative effect was found only in labourers (OR $1.46,7 \cdot 6,22 \cdot 2$ respectively in exposed non smokers, smokers of 1-14 cigarettes a day and smokers of more than 15 cigarettes a day; OR 4.6 and 8.2 for the unexposed smokers categories). A similar picture was found also 
for gunsmiths, even if it was difficult to evaluate, as there were no cases in the exposed nonsmokers category. In this study, the interviewer, who was a medical doctor, was informed of the case-control status. This was because cases and controls were located in different wards or hospitals especially created for the different diseases. Therefore, it was extremely difficult - if not impossible - not to be aware of the diagnosis. The coder of the occupational section of the questionnaire also was not blind to the case-control status, mainly because of logistic aspects. Anyway, at the end of the study, the coder himself made a blind recoding of all questionnaires and no substantial disagreement was found. Moreover, a partially blind recoding was made by another investigator and again no relevant disagreement was found. Furthermore, should a bias arise because the interviewer was not blind, it is likely to be against the null hypothesis, causing more jobs and industrial categories to be found falsely associated with the disease than there actually are. Our results, however, tend to be in the opposite direction, as a small number of categories was found significantly associated with the disease.

As far as the choice of hospital based controls, it is a well practiced alternative to population based controls in case control studies. According to many authors, no bias is expected to be introduced, provided that the diseases selected for the control series are not causally linked with the exposure under study and with relevant confounders such as tobacco smoking for bladder cancer. In this investigation, none of the diseases used for the recruitment of controls is known to be related either to the occupational exposures or lifestyle factors such as tobacco smoking, coffee, or alcohol drinking. 3536

It should also be noted that bias due to survival is not likely, as analyses restricted to incident cases confirmed the results based on the whole series. However, as the incident cases are relatively few, they provide only a partial test of survival bias.

In conclusion, this study suggested that in the province of Brescia a few occupational exposures could be associated with the risk of bladder cancer. Some of these might be due to chance or be artefacts due to the study design, some confirm earlier findings of other studies, some suggest possible aetiological factors. Bladder cancer should still be considered as an index of hazard of occupational cancer, especially in highly industrialised areas with various occupational exposures.

This work was partially supported by the Lega Italiana per la Lotta contro i Tumori, Brescia, Italy.

1 International Agency for Research on Cancer. LARC mono graphs on the evaluation of the carcinogenic risk of chemicals to humans. Overall evaluations of carcinogenicity: an updating of IARC monographs. Vols 1 to 42, suppl 7. Lyon France: IARC, 1987.

2 British Association of Urological Surgeons (BAUS) subcommittee on industrial bladder cancer. Occupationa bladder cancer: a guide for clinicians. Br $\mathcal{f}$ Urol 1988; 61:183-91.

3 Silverman DT, Hartge P, Morrison AS, Devesa SS Epidemiology of bladder cancer. Haematol Oncol Clin North Am 1992;6:1-30.
4 Jensen OM, Wahrendorf J, Knudsen JB, Sorensen BL. The Copenhagen case referent study on bladder cancer. Risks among drivers, painters, and certain other occupations. Scand $\mathcal{F}$ Work Environ Health 1987;13:129-34

5 Malker HSR, McLaughlin JK, Silverman DT, Ericsson JLE, Stone BJ, Weiner JA, et al. Occupational risk factors for bladder cancer among men in Sweden. Cancer Res 1987;47:6763-6.

6 Claude JC, Frentzel-Beyme RR, Kunze E. Occupation and risk of cancer of the lower urinary tract among men. A case-control study. Int $f$ Cancer 1988;41:371-9.

7 Risch HA, Burch JD, Miller AB, Hill GB, Steele R, Howe GR. Occupational factors and the incidence of cancer of the bladder in Canada. Br f Ind Med 1988;45:361-7.

8 Silverman DT, Levin LI, Hoover RN, Hartge P. Occupational risks of bladder cancer in the United States: I White men. $f$ Natl Cancer Inst 1989;81:1472-80.

9 Steineck G, Plato N, Norell SE, Hogstedt C. Urothelial cancer and some industry-related chemicals: an evaluation of the epidemiologic literature. Am F Ind Med 1990; 17:371-91.

10 Myslak ZD, Bolt HM, Brockmann W. Tumors of the urinary bladder in painters. A case-control study. $A m \mathcal{F}$ Ind Med 1991;19:705-13.

11 Dolin PJ. A descriptive study of occupation and bladder cancer in England and Wales. Br 7 Cancer 1992;65: 476-8.

12 Zheng W, McLaughlin JK, Gao YT, Silverman DT, Gao RN, Blot WJ. Bladder cancer and occupation in Shangai, 1980-4. Am f Ind Med 1992;21:877-85.

13 Cordier S, Clavel J, Limasset JC, Boccon-Gibod L, Le Moual N, Mandereau L, Hemon D. Occupational risk of bladder cancer in France: a multicentre case-control study. Int $\mathcal{f}$ Epidemiol 1993;22:403-11.

14 Barbone F, Franceschi S, Talamini R, Bidoli E, La Vecchia C. Occupation and bladder cancer in Pordenone (northeast Italy): a case-control study. Int $\mathcal{F}$ Epidemiol 1994;23 58-65.

15 Bonassi S, Merlo F, Pearce N, Puntoni R. Bladder cancer and occupational exposure to polycyclic aromatic hydroand occupational exposure to polycyctic

16 Vineis $P$, Simonato L. Estimation of the proportion of blad der cancers attributable to occupation. Scand 7 Work Environ Health 1986;12:55-60.

17 Decarli A, La Vecchia C. Cancer mortality in Italy, 1991. Tumori 1994;80:405-15.

18 Mostofi FK, Sobin LH, Torloni H. Hystological typing of urinary bladder tumours. International hystological classification of tumours, No 10. Geneva: World Health Organisation, 1973.

19 International Labour Office. International standard classification of occupations. Revised edition. Geneva: ILO, 1968.

20 United Nations. International standard industrial classification of all economic activities. New York: UN, 1968. (Series M, No 4, Rev 2.)

21 International Agency for Research on Cancer. IARC Monographs on the evaluation of the carcinogenic risk of Monographs on the evaluation of the carcinogenic risk of France: IARC, 1988.

22 Breslow NE, Day NE. Statistical methods in cancer research. Vol 1. The analysis of case-control studies. Lyon, France: 1980. (IARC Sci Publication No32.)

23 Clayton D, Hills M. Statistical models in epidemiology. Oxford: Oxford University Press, 1993.

24 Dixon WJ. BMDP Statistical software manual. Berkeley: California University Press, 1992.

25 Becherini R, Seniori Costantini A, Benelli R, Calistri S, Gasperini MM, Gavazzi M, et al. Tumori delle vie urinarie negli addetti all'industria tessile nell'area pratese. Med Lav 1991;82:492-503.

26 Schumacher MC, Slattery ML, West DW. Occupation and bladder cancer in Utah. Am 7 Ind Med 1989;16:89-102.

27 Burkhart G, Schulte PA, Robinson C, Sieber WK, Vossenas P, Ringen K. Job tasks, potential exposures, and health risks of laborers employed in the construction industry. Am F Ind Med 1993;24:413-25.

28 Keller JE, Howe HL. Cancer in Illinois construction workers: a study. $A m \mathcal{F}$ Ind $M e d$ 1993;24:223-30

29 Wortley P, Vaughan TL, Davis S, Morgan MS, Thoma DB. A case control study of occupational risk factors for laryngeal cancer. $\mathrm{Br}$ f Ind Med 1992;49:837-44.

30 Gonzales CA, Lopez-Abente G, Errezola M, Escolar A Riboli E, Izarzugaza I, Nebot $M$. Occupation and bladder cancer in Spain: a multi centre case control study. In f Epidemiol 1989;18:569-77.

31 Silverman DT, Hoover RN, Mason TJ, Swanson MG. Motor exhaust related occupations and bladder cancer. Cancer Res 1986;46:2113-6.

32 Schifflers E, Jamart J, Renard V. Tobacco and occupation as risk factors for bladder cancer: a case-control study in southern Belgium. Int $f$ Cancer 1987;39:287-92.

33 Vineis P, Magnani C. Occupation and bladder cancer in males: a case-control study. Int $\mathcal{f}$ Cancer 1985;35: 599-606.

34 Vineis P, Simonato L. Proportion of lung and bladder cancers due to occupation: a systematic approach. Arch Environ Health 1991;46:6-15.

35 Wacholder S, McLaughlin JK, Silverman DT, Mandel JS Selection of controls in case-control studies. I. Principles Am $\mathcal{F}$ Epidemiol 1992;135:1019-28.

36 Wacholder S, Silverman DT, McLaughlin JK, Mandel JS Selection of controls in case-control studies. II. Types of controls. Am F Epidemiol 1992;135:1029-41. 